\title{
Detection, Survival, and Sources of Inoculum for Bacterial Diseases of Leafy Crucifers in Oklahoma
}

\author{
Youfu Zhao, John P. Damicone, and Carol L. Bender, Department of Entomology and Plant Pathology, Okla- \\ homa State University, Stillwater 74078
}

\begin{abstract}
Zhao, Y. F., Damicone, J. P., and Bender, C. L. 2002. Detection, survival, and sources of inoculum for bacterial diseases of leafy crucifers in Oklahoma. Plant Dis. 86:883-888.

Xanthomonas campestris pv. campestris, X. campestris pv. armoraciae, and Pseudomonas syringae pv. maculicola are bacterial pathogens that cause leaf spot diseases on leafy crucifers in Oklahoma. Polymerase chain reaction (PCR) amplification of the $c f l$ gene from the gene cluster encoding the phytotoxin coronatine was used to identify coronatine-producing strains of $P$. syringae, and the expected $0.65-\mathrm{kb}$ PCR product was detected in 19 strains of $P$. syringae pv. maculicola originating from diseased crucifers in Oklahoma. A simple, rapid PCR method based on primers from the $c f l$ gene was developed to detect coronatine-producing strains of $P$. syringae in planta. Pathogenicity tests confirmed the $c f l$-positive strains to be $P$. syringae pv. maculicola. To monitor the survival of $X$. campestris pv. armoraciae and P. syringae pv. maculicola in the field, turnip and collards were inoculated with rifampicin-resistant strains and were buried beneath the soil or left on the soil surface. Both pathogens were recovered from turnip and collard debris up to 2 months following burial, but neither pathogen was recovered from soil after the debris had decomposed. However, both pathogens were recovered from plant debris left on the soil surface for up to 5 months. Four production fields were surveyed for sources of inoculum of the bacterial pathogens from October 1999 to May 2000. X. campestris pv. campestris was isolated from the weed shepherd's purse (Capsella bursa-pastoris) in all fields, and from volunteer turnip and kale in three fields. X. campestris pv. campestris and P. syringae pv. maculicola were isolated from surface debris and regrowth from crop stubble left in one field after harvest in the fall. X. campestris pv. campestris was detected in 6 of 51 lots of crucifer seed assayed. $X$. campestris pv. armoraciae and $P$. syringae pv. maculicola were not recovered from weeds, volunteer plants, or seed lots.
\end{abstract}

Since 1994, collards (Brassica oleracea var. viridis L.), kale (B. oleracea var. sabellica L.), spinach mustard (B. rapa L. var. perviridis Bailey), and turnip (B. rapa var. utilis (D.C.) Metzg.) have been damaged periodically by bacterial leaf spots in eastern Oklahoma $(33,34)$. Severely damaged fields have been rejected for harvest by processors, causing total economic loss. Xanthomonas campestris pv. campestris, $X$. campestris pv. armoraciae, and Pseudomonas syringae pv. maculicola were identified as causal agents of leaf spots on these crops $(33,34)$. These bacteria often occurred together within an affected field. Genetic and phenotypic diversities were high for strains of $X$. campestris originating from different fields, but were often similar within fields. Strains of $P$. syringae pv. maculicola from most fields were relatively homogeneous and within the same genetic group.

Control of bacterial leaf spots on leafy crucifers in Oklahoma has proven to be

Corresponding author: John P. Damicone

E-mail:.jpd3898@okstate.edu

Accepted for publication 17 April 2002.

Publication no. D-2002-0614-02R

(C) 2002 The American Phytopathological Society difficult. The use of bactericidal sprays containing copper compounds has not been effective. Therefore, other management strategies are necessary to reduce losses. The identification of inoculum sources for the diseases should result in cultural practices designed to prevent disease outbreaks through a reduction and/or elimination of primary inoculum.

$X$. campestris pv. campestris, the cause of black rot, also causes leaf spot on leafy crucifers (33). Plant debris $(16,25)$, seed $(18,26)$, and weeds $(24,30)$ are reported most often to be important sources of inoculum for black rot. However, the survival of $X$. campestris pv. campestris on plant debris depends on field conditions and temperature $(2,16,25)$.

$X$. campestris pv. armoraciae, the cause of Xanthomonas leaf spot (5), and P. syringae pv. maculicola, the cause of bacterial leaf spot $(6,28)$, are important bacterial pathogens of leafy crucifers in Oklahoma $(33,34)$. Although these two pathogens may be seedborne $(18,27)$, there is little information available on their survival in plant debris, and it is unclear whether weeds also serve as inoculum sources for these pathogens.

This study was undertaken to identify important sources of inoculum for bacterial leaf spot disease of leafy crucifers in Oklahoma. Specific objectives were to deter- mine the survival of $X$. campestris pv. armoraciae and $P$. syringae pv. maculicola in plant debris, and to assess the potential for plant debris, weeds, seed, or volunteer plants to serve as inoculum sources for these pathogens as well as $X$. campestris pv. campestris. Because selective media are not available for $P$. syringae, a rapid polymerase chain reaction (PCR) method was developed to detect coronatineproducing strains in order to putatively differentiate $P$. syringae pv. maculicola from xanthomonads and other fluorescent pseudomonads. Preliminary reports have been published $(31,32)$.

\section{MATERIALS AND METHODS}

Bacterial strains and pathogenicity. The strains of $P$. syringae used in this study (Table 1 ) were routinely cultured on King's medium B $(\mathrm{KB} ; 15)$ or mannitol-glutamate medium (MG; 14) at $28^{\circ} \mathrm{C}$ and stored in $15 \%$ glycerol at $-70^{\circ} \mathrm{C}$. X. campestris pv. armoraciae strain BR16 and $P$. syringae pv. maculicola strain F18 were previously isolated from turnip in Oklahoma (Table 1). Spontaneous rifampicin-resistant mutants of both strains were selected by plating bacterial cells onto Luria-Bertani (LB; 21) or MG medium containing rifampicin at $100 \mu \mathrm{g} / \mathrm{ml}$.

The pathogenicity of the rifampicinresistant strains of $X$. campestris pv. armoraciae (BR16R) and $P$. syringae pv. maculicola (F18R) was confirmed to be similar to the wild-types (BR16 and F18) using spray inoculation as described previously $(33,34)$. Briefly, strains were grown on $\mathrm{LB}$ or MG with or without rifampicin $(50 \mu \mathrm{g} / \mathrm{ml})$ for the resistant mutants or wild-types, respectively, at $28^{\circ} \mathrm{C}$ for $48 \mathrm{~h}$. Cells were then suspended in sterile distilled water (SDW) and adjusted to $10^{7}$ $\mathrm{CFU} / \mathrm{ml}$ as determined by dilution plating and OD readings $\left(A_{600}=0.05\right)$. Plants were grown in the greenhouse at 20 to $25^{\circ} \mathrm{C}$ until three to four true leaves formed. Collard (cv. Vates) and turnip (cv. Hybrid Alltop) plants were incubated in polyethylene chambers within the greenhouse at $100 \%$ relative humidity for 24 to $48 \mathrm{~h}$ before and after inoculation. Bacterial suspensions were applied with an airbrush at $172 \mathrm{kPa}$ until the leaves were uniformly wet. After inoculation, plants were removed from the chambers and maintained in the greenhouse until symptoms were assessed 7 to 14 days after inoculation.

PCR detection of $P$. syringae. Bacterial strains (Table 1) were grown in $5 \mathrm{ml}$ of LB 
broth at $28^{\circ} \mathrm{C}, 280 \mathrm{rpm}$, for $18 \mathrm{~h}$. Aliquots $(1 \mathrm{ml})$ were centrifuged, and pellets were washed in $0.5 \mathrm{M} \mathrm{NaCl}(0.5 \mathrm{ml})$ and resuspended in SDW to $10^{8} \mathrm{CFU} / \mathrm{ml}$. PCR amplification was performed in 25 - $\mu$ l reaction volumes. Each reaction contained $\mathrm{Taq}$ reaction buffer, $1.5 \mathrm{mM} \mathrm{MgCl} 2,50$ pmoles of each primer, $0.05 \mathrm{mM}$ of each dNTP (Boehringer Mannheim, Indianapolis, IN), 0.5 U Taq DNA polymerase (Promega, Madison, WI), and $1 \mu \mathrm{l}$ of the bacterial suspension. Oligonucleotides with the sequence 5'-GGCGCTCCCTCGCACTT (primer 1) and 5'-GGTATTGGCGGG GGTGC (primer 2) were used to amplify the $c f l$ gene, which is encoded within the coronatine (COR) gene cluster (4). Primers were synthesized by the Oklahoma State University Recombinant DNA/Protein Resource Facility. PCR was carried out as follows: 1 cycle at $94^{\circ} \mathrm{C}$ for $3 \mathrm{~min}, 30$ cycles at $94^{\circ} \mathrm{C}(1 \mathrm{~min}), 67^{\circ} \mathrm{C}(1 \mathrm{~min})$, and $72^{\circ} \mathrm{C}(1 \mathrm{~min})$, followed by $72^{\circ} \mathrm{C}$ for 10 min. A $10-\mu l$ aliquot of the reaction was analyzed by electrophoresis on a $1 \%$ agarose gel at $70 \mathrm{~V}$ for $2 \mathrm{~h}$ in Tris acetate buffer (21). Gels were stained with

A simple PCR assay for detecting CORproducing pathovars of $P$. syringae in plant tissue was developed. Briefly, a $1 \mathrm{~cm}^{2}$ diameter leaf disk with a lesion was excised, surface-sterilized in $0.25 \%$ aqueous sodium hypochlorite for $30 \mathrm{~s}$, and washed three times in SDW. The disk was cut into several pieces in $500 \mu \mathrm{lDW}$, allowed to ethidium bromide.

soak for $10 \mathrm{~min}$, and pelleted at $325 \times \mathrm{g}$ for $2 \mathrm{~min}$. The supernatant was centrifuged at $16,000 \times g$ for $10 \mathrm{~min}$; the pellet was washed with $0.5 \mathrm{M} \mathrm{NaCl}(0.5 \mathrm{ml})$, resuspended in $20 \mu \mathrm{l} \mathrm{SDW}$, and used as template in the PCR reaction.

The PCR assay was verified using plants spray-inoculated with known bacteria and with unknown samples of diseased leaves collected in the field. Turnip, collard, and tomato (cv. Summer Flavor 3000) plants were inoculated as described above with $P$. syringae pv. maculicola strains 84-59 and F18, and $P$. syringae pv. tomato DC3000. Healthy plants and plants inoculated with $X$. campestris pv. armoraciae or $P$. viridiflava were used as negative controls. Disks excised from three leaves for each plant type and inoculation treatment were analyzed for the presence of the $c f l$ gene by PCR as described above. The assay was performed three times. Diseased turnip and spinach mustard leaves were sampled from the fields described below over a 2-year period. Disks excised from three to five leaves per field were analyzed by PCR using the $c f l$ primer set. Diseased turnip and collard leaves produced by spray inoculation and healthy leaves served as positive and negative controls, respectively. Bacterial isolations were made from adjacent leaf disks on MG amended with cycloheximide. At least one colony resembling $P$. syringae from each $c f l$ positive leaf disk was characterized by PCR using the $c f l$ primer set and pathogenicity tests on collards or turnip.

Table 1. Detection of coronatine-producing strains of Pseudomonas syringae by polymerase chain reaction (PCR)

\begin{tabular}{|c|c|c|c|}
\hline Strain & Host & $c f l-\mathbf{P C R}^{\mathrm{a}}$ & Source (reference) ${ }^{\mathbf{b}}$ \\
\hline \multicolumn{4}{|l|}{ P. syringae pv. maculicola } \\
\hline NF2, F6, F18, F19, NF3, NF3a & Turnip & + & OK (34) \\
\hline \multicolumn{4}{|l|}{ NF4, NF5, NF12, F1, F7, F16, } \\
\hline F17, F20, F21, F22 & Spinach mustard & + & OK (34) \\
\hline F9, F10a, F15 & Kale & + & OK (34) \\
\hline 16391,16392 & Cauliflower & + & R. Stall (34) \\
\hline 17223,17225 & Brassica sp. & + & R. Stall (34) \\
\hline $84-67$ & Cauliflower & - & D. Cuppels $(28,34)$ \\
\hline $84-59,88-10,88-11,90-32$ & Cauliflower & + & D. Cuppels $(28,34)$ \\
\hline 4326 & Radish & + & C. Bender $(28,34)$ \\
\hline \multicolumn{4}{|l|}{ P. syringae pv. tomato } \\
\hline DC3000 & Tomato & + & D. Cuppels (34) \\
\hline \multicolumn{4}{|l|}{ P. syringae pv. glycinea } \\
\hline PG4180 & Soybean & + & C. Bender \\
\hline $18 \mathrm{a} / 90$ & Soybean & - & C. Bender \\
\hline P. viridiflava & Brassica sp. & - & OK (34) \\
\hline P. putida & Brassica sp. & - & OK (34) \\
\hline P. fluorescens & Brassica sp. & - & OK (34) \\
\hline \multicolumn{4}{|c|}{ Xanthomonas campestris pv. campestris } \\
\hline BR40 & Cabbage & - & OK (33) \\
\hline Xcc528 & Brussels sprouts & - & ATCC $33913(1,33)$ \\
\hline \multicolumn{4}{|l|}{$X$. campestris pv. armoraciae } \\
\hline BR 16 & Turnip & - & OK (33) \\
\hline XLS6 & Cabbage & - & L. Black $(1,33)$ \\
\hline \multicolumn{4}{|c|}{$\begin{array}{l}\text { a PCR analysis with primers from the } c f l \text { gene (4) was carried out using bacterial cells as template. }+ \\
\text { the } 650 \text {-bp PCR product was detected; - , no PCR product was observed. }\end{array}$} \\
\hline \multicolumn{4}{|c|}{$\begin{array}{l}\text { b Strains were from C. Bender, coauthor; D. Cuppels, Agriculture and Agri-Food Canada, London, } \\
\text { Ontario, Canada N5V 4T3; R. Stall, Department of Plant Pathology, University of Florida, Gaines- } \\
\text { ville 32611; and L. Black, Department of Plant Pathology and Crop Physiology, Louisiana State } \\
\text { University, Baton Rouge 70803. Strains from OK were isolated from diseased leaves sampled from } \\
\text { local fields as previously reported (33,34). }\end{array}$} \\
\hline
\end{tabular}

Survival of $X$. campestris pv. armoraciae and $P$. syringae pv. maculicola in plant debris. Survival studies were conducted at the OSU Plant Pathology Farm in Stillwater in microplots that contained Norge loam soil ( $\mathrm{pH}$ 6.2). Microplots were $2 \times 2 \mathrm{~m}$, raised $25 \mathrm{~cm}$ high with railroad timbers, and were each surrounded by a 3 m-wide alley. Crucifers had not been grown in these plots for at least 5 years, and wheat was the only crop planted in the surrounding area. Granular fertilizer (42-0$0 \mathrm{~N}-\mathrm{P}-\mathrm{K}$ ) at $84 \mathrm{~kg} / \mathrm{ha}$ was incorporated into the soil prior to direct seeding. Two plots each of turnip and collard were seeded on 20 September 1998, 9 October 1998, and 14 September 1999. In 1998, the two lateseeded plots of collard were later discarded because of frost damage prior to inoculation. One plot of each crop was inoculated with $P$. syringae pv. maculicola F18R and the other with $X$. campestris pv. armoraciae BR16R on 5 and 19 November for the early- and late-planted plots in 1998, respectively, and on 14 October in 1999. The inoculations consisted of spraying all plants in a plot to runoff with bacteria $\left(10^{7}\right.$ $\mathrm{CFU} / \mathrm{ml}$ ) suspended in SDW. Plants were uprooted and then buried ca. $10 \mathrm{~cm}$ below the soil surface on 23 November and 14 December for the early- and late-planted plots in 1998, respectively, and on 30 October in 1999. Additionally, half of the uprooted plants were left on the soil surface for the late-planted plots in 1998 and for the plots planted in 1999. Beginning immediately after burial, six or more plants were unearthed from each plot at 30-day intervals. The surface debris also was sampled at 30-day intervals. When buried and surface debris were decayed and could no longer be recovered, three to five soil samples ( $2 \mathrm{~g}$ each) were collected from the treated area and assayed for rifampicinresistant $X$. campestris and $P$. syringae.

To detect rifampicin-resistant strains, samples were weighed and macerated in 10 to $20 \mathrm{ml} \mathrm{SDW}$ using a mortar and pestle. Serial dilutions were made in SDW, and $25-\mu \mathrm{l}$ aliquots were spotted onto the surface of four replicate plates per dilution. Nutrient agar (NA; 19) and MG medium amended with cycloheximide $(100 \mu \mathrm{g} / \mathrm{ml})$ and rifampicin $(50 \mu \mathrm{g} / \mathrm{ml})$ were used to isolate $X$. campestris and $P$. syringae, respectively. The plates were dried in a laminar flow hood and incubated at $28^{\circ} \mathrm{C}$ for 3 to 5 days. Rifampicin-resistant colonies of $X$. campestris and $P$. syringae were counted, and the recovery of bacteria per gram fresh weight was calculated.

Field surveys. In the fall of 1999 and spring of 2000, four fields in the Arkansas River Valley, each with a history of bacterial disease(s), were surveyed for potential sources of inoculum. Fields 1 and 2 were located near Tucker, OK. Field 1 had a history of bacterial leaf spot $(P$. syringae pv. maculicola), and field 2 had a history of black rot (X. campestris pv. campestris). 
Fields 3 and 4 were located in Webbers Falls, OK. Field 3 had a history of bacterial leaf spots caused by $X$. campestris pvs. campestris and armoraciae and $P$. syringae pv. maculicola, while field 4 had a history of black rot. Fields were surveyed twice each in the fall and spring production seasons. The first survey was on 29 October 1999 when the fall crop of leafy crucifers was near harvest and diseases were fully developed, and the second was on 16 December 1999 after harvest. The third survey was on 16 March 2000 during field preparation for the spring production season, and the final survey was on 17 May 2000 when the spring crop of leafy crucifers was near harvest and diseases were fully developed. Fields varied in crop rotations, but each was planted to leafy crucifers at least once during the survey period (Table 2).

Fields and surrounding vegetation were sampled in a w-shaped pattern. Leaves of cruciferous crops, plant stubble remaining after harvest, crop debris, and volunteer cruciferous plants with symptoms resembling bacterial disease were collected, placed in plastic bags, chilled, and transported to the laboratory. Broadleaf weeds were collected regardless of symptom manifestation. Bacteria were isolated from suspected lesions as previously described $(33,34)$. Asymptomatic weeds were assayed for bacterial pathogens by shaking leaf sections in SDW $(10 \mathrm{ml})$ for $20 \mathrm{~min}$ at $4^{\circ} \mathrm{C}$. Serial dilutions of the suspension were made in SDW, and 0.1-ml aliquots were plated on Fieldhouse-Sasser (FS) medium (9) and MG amended with cycloheximide $(100 \mu \mathrm{g} / \mathrm{ml})$. Suspected xanthomonads were selected, and pathogenicity was determined using the cabbage cotyledon assay which differentiates the pathovars campestris and armoraciae (1).
MG and KB amended with cycloheximide were used to isolate $P$. syringae, and coronatine-producing strains of $P$. syringae were differentiated from other fluorescent pseudomonads by PCR.

Seed assays. Preliminary assays were performed to assess recovery of $X$. campestris pv. armoraciae and $P$. syringae pv. maculicola from artificially inoculated seed. Noninfested seed was soaked in a bacterial suspension $\left(10^{8} \mathrm{CFU} / \mathrm{ml}\right)$ of BR16R or F18R for $5 \mathrm{~min}$ and air-dried. Inoculated seed was added to noninfested seed at ratios of $0,1,10$, and 100 inoculated seeds per $20 \mathrm{~g}$ of clean seed. Bacteria were isolated from seed as described by Schaad (22). Briefly, seeds (20 g) were shaken in $50 \mathrm{ml}$ of $0.1 \mathrm{M}$ phosphatebuffered saline (PBS; pH 7.2) on a rotary shaker for $1 \mathrm{~h}$ at $4^{\circ} \mathrm{C}$. The supernatant was filtered through two layers of cheesecloth and centrifuged at $17,600 \times g$ for $30 \mathrm{~min}$. The pellet was resuspended in $2 \mathrm{ml} \mathrm{SDW}$, diluted in SDW, and plated in 0.1-ml aliquots to FS medium and nutrient starch cycloheximide antibiotic agar (NSCAA) to detect xanthomonads (20). FS and NSCAA plates were incubated for 3 to 5 days, and colonies with a clear zone of starch hydrolysis were selected. The cabbage cotyledon assay was performed to differentiate the two pathovars of $X$. campestris. MG and $\mathrm{KB}$ amended with cycloheximide were used to isolate $P$. syringae. After a 48-h incubation period, Bio-PCR (23) was performed on selected plates using the $c f l$ primer set. Four days after incubation, suspected colonies were used in a standard PCR reaction using the $c f l$ primer set.

The seed assays were performed on 51 commercial seed lots collected from five different companies during 1995 to 1999. The seed lots consisted of nine lots of collard, eight lots of kale, seven lots of mus- tard, twelve lots of turnip, five lots of spinach mustard, four lots of Chinese cabbage, five lots of broccoli, and one lot of cabbage.

\section{RESULTS}

PCR detection of $P$. syringae. With the exception of strains 84-67 and 18a/90, which served as negative controls, PCR analysis of strains of $P$. syringae pvs. maculicola, glycinea, and tomato resulted in the expected $0.65-\mathrm{kb}$ PCR product (Table 1, Fig. 1A). Analysis of four strains of $P$. syringae pv. maculicola (NF3, NF4, 16391, and 16392) that did not produce detectable COR in vitro (34) resulted in the 0.65-kb PCR product (Table 1; Fig. 1A, lanes 5 and 6). No PCR products were detected for the COR-nonproducing bacteria that included $P$. viridiflava (4 strains), $P$. fluorescens (4 strains), P. putida (3 strains), and $X$. campestris pvs. campestris (2 strains) and armoraciae (2 strains) (Table 1; Fig. 1A, lane 10).

PCR amplification with the $c f l$ primers was also conducted with healthy and diseased leaf extracts. The expected $0.65-\mathrm{kb}$ PCR product was detected from leaf extracts of tomato, turnip, and collard inoculated with all of the COR-producing strains of $P$. syringae (Fig. 1B; lanes 2, 4, and 7). No PCR product was observed for healthy turnip, tomato, and collard; or for leaves inoculated with $X$. campestris pv. campestris, $X$. campestris pv. armoraciae, and $P$. viridiflava (Fig. 1B, lanes 1, 5, and 6). The expected $0.65-\mathrm{kb}$ PCR product was detected from leaf extracts of turnip and spinach mustard showing leaf spot symptoms in the field (Fig. 1B, lane 3). When bacteria were isolated from leaves that were $c f l$-positive, the $0.65-\mathrm{kb}$ product was obtained from individual colonies when further analyzed by PCR, and they were

Table 2. Recovery of bacterial leaf spot pathogens of leafy crucifers during field surveys

\begin{tabular}{|c|c|c|c|c|c|c|c|}
\hline \multirow[b]{2}{*}{ Field } & \multicolumn{2}{|c|}{ Crop } & \multirow[b]{2}{*}{ Pathogen $^{a}$} & \multicolumn{4}{|c|}{ Site of recovery ${ }^{b}$} \\
\hline & Fall 99 & Spring 00 & & 29 Oct 99 & 16 Dec 99 & 16 Mar 00 & 17 May 00 \\
\hline \multirow[t]{4}{*}{1} & Spinach mustard & Spinach mustard & PSM & Crop & NR & NR & Crop \\
\hline & & & XCA & $\mathrm{NR}$ & NR & NR & Crop \\
\hline & & & $\mathrm{XCC}$ & Crop & Volunteers & Volunteers & Crop \\
\hline & & & & & & Weeds & Weeds \\
\hline \multirow[t]{4}{*}{2} & Spinach mustard & Snap bean & PSM & NR & NR & NR & NR \\
\hline & & & $\mathrm{XCA}$ & NR & NR & NR & NR \\
\hline & & & $\mathrm{XCC}$ & Crop & Volunteers & Volunteers & Weeds \\
\hline & & & & Weeds & Weeds & Weeds & \\
\hline \multirow[t]{7}{*}{3} & Collards, turnip & Corn & PSM & Crop & Debris & Debris & NR \\
\hline & & & & & Regrowth & Regrowth & \\
\hline & & & XCA & NR & NR & NR & NR \\
\hline & & & $\mathrm{XCC}$ & Crop & Debris & Debris & Weeds \\
\hline & & & & Weeds & Weeds & Weeds & \\
\hline & & & & & Regrowth & Regrowth & \\
\hline & & & & & Volunteers & Volunteers & \\
\hline \multirow[t]{3}{*}{4} & Spinach mustard & Spinach mustard & PSM & NR & NR & NR & Crop \\
\hline & & & $\mathrm{XCA}$ & NR & NR & NR & NR \\
\hline & & & $\mathrm{XCC}$ & Crop & NR & Weeds & Crop \\
\hline
\end{tabular}

${ }^{a} \mathrm{PSM}=$ Pseudomonas syringae pv. maculicola $; \mathrm{XCA}=$ Xanthomonas campestris pv. armoraciae $; \mathrm{XCC}=X$. campestris pv. campestris.

b Volunteers were turnip and kale in fields 1 and 2, and turnip in field 3. Among the weeds sampled in each field, shepherd's purse (Capsella bursapastoris) was the only weed that harbored pathogens. Debris $=$ surface crop debris; regrowth $=$ new growth from crop stubble; NR $=$ no recovery. 
pathogenic to crucifers and tomato (data not shown). The estimated concentration of total bacteria at the time of detection was approximately $10^{7} \mathrm{CFU} / \mathrm{g}$ fresh weight as determined by dilution plating.

Pathogen survival. Mean monthly temperatures and total rainfall recorded within $0.5 \mathrm{~km}$ from the test site were $11.3^{\circ} \mathrm{C}$ and $14 \mathrm{~cm}$ for November $1998,4.3^{\circ} \mathrm{C}$ and 3.8 $\mathrm{cm}$ for December $1998,3.1^{\circ} \mathrm{C}$ and $4.1 \mathrm{~cm}$ for January $1999,9.4^{\circ} \mathrm{C}$ and $1.8 \mathrm{~cm}$ for February $1999,8.8^{\circ} \mathrm{C}$ and $10.4 \mathrm{~cm}$ for March 1999 , and $16.0^{\circ} \mathrm{C}$ and $17.5 \mathrm{~cm}$ for April 1999. Rifampicin-resistant $X$. campestris $\mathrm{pv}$. armoraciae and $P$. syringae pv. maculicola were recovered from plant debris for 2 months after burial during 1998 and 1999 (Fig. 2). Each pathogen survived on both early- and late-planted turnip, and on early-planted collards. The plant debris remained intact for the first 2 months, but was decomposed within 3 months and could not be recovered. Rifampicin-resistant $X$. campestris pv. armoraciae and $P$. syringae pv. maculicola were not isolated from the soil after the debris had decayed. However, both pathogens were recovered from turnip debris left on the soil surface for up to 4 months (Fig. 2). No debris remained on the soil surface after 5 months, and the pathogens were not recovered from surrounding soil. While populations of $P$. syringae pv. maculicola were often higher than for $X$. campestris pv. armoraciae, population trends and the duration of survival were similar for both pathogens over the sampling periods.

Mean monthly temperatures and rainfall were $12.9^{\circ} \mathrm{C}$ and $0 \mathrm{~cm}$ for November 1999 , $5.6^{\circ} \mathrm{C}$ and $15.1 \mathrm{~cm}$ for December 1999 , $3.7^{\circ} \mathrm{C}$ and $2.0 \mathrm{~cm}$ for January $2000,8.5^{\circ} \mathrm{C}$ and $3.0 \mathrm{~cm}$ for February $2000,11.3^{\circ} \mathrm{C}$ and
$11.2 \mathrm{~cm}$ for March 2000 , and $15.0^{\circ} \mathrm{C}$ and $9.1 \mathrm{~cm}$ for April 2000. Plant debris remained intact for less than a month when buried in 1999. Rifampicin-resistant $X$. campestris pv. armoraciae and $P$. syringae pv. maculicola were not recovered from soil after the debris had decayed. However, debris on the soil surface remained intact, and rifampicin-resistant $X$. campestris pv. armoraciae and $P$. syringae pv. maculicola were recovered from both collard and turnip for 4 and 5 months, respectively (Fig. 3). Pathogen survival was again similar for the two hosts and pathogens during the sampling periods.

Field surveys. $X$. campestris pv. campestris was recovered from shepherd's purse (Capsella bursa-pastoris) in two fields in fall 1999 and from all four fields in spring 2000 (Table 2). Shepherd's purse was the primary cruciferous weed observed in the fields. Symptoms on this weed included marginal, V-shaped, chlorotic, and necrotic lesions on the leaves. The cotyledon assay confirmed that bacterium isolated from shepherd's purse was $X$. campestris pv. campestris. No pathogenic bacteria were recovered from other broadleaf weeds, including Rumex sp. and Virginia pepperweed (Lepidium virginicum). Although fluorescent pseudomonads were isolated from most weeds, none were $c f l$ positive when analyzed by PCR .

In December 1999 and March 2000, volunteer kale and turnip were common in and around the surveyed fields. X. campestris pv. campestris was recovered from volunteer plants in three of the four fields (Table 2). In October 1999 and May 2000, bacterial leaf spot diseases were observed in all of the fields where crucifers were cropped (Table 2). All three pathogens

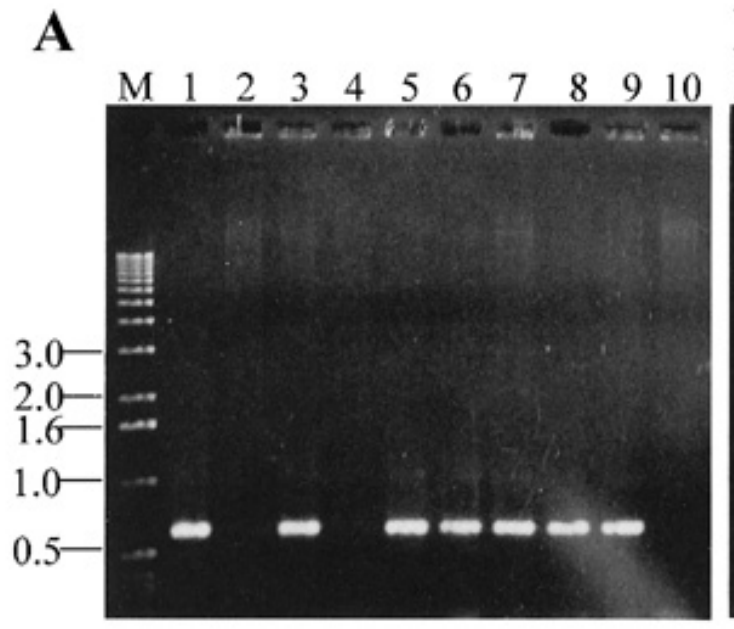

\section{B}

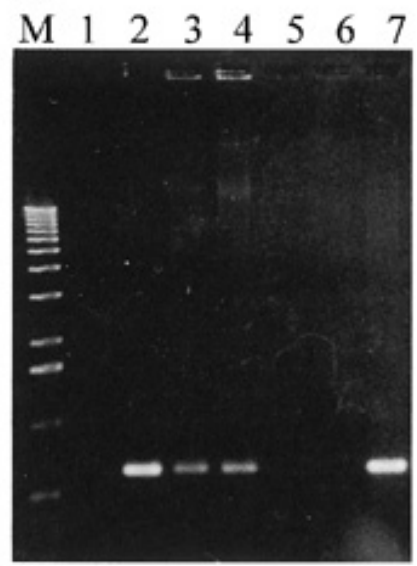

Fig. 1. Polymerase chain reaction (PCR) products amplified using the $c f l$ primer set (4). A, PCR products from bacterial cells. Lanes: 1, PG4180; 2, 18a/90; 3, F18; 4, 84-67; 5, NF4; 6, 16392; 7, 8459; 8, F20; 9, 4326; 10, Pseudomonas viridiflava; M, molecular size marker (1-kb ladder). B, PCR products from leaf extracts. Lanes: 1, healthy turnip leaf; 2, tomato leaf inoculated with DC3000; 3 , diseased turnip leaf from a field with bacterial leaf spot caused by Pseudomonas syringae pv. maculicola; 4, collard leaf inoculated with $P$. syringae pv. maculicola 84-59; 5, turnip leaf inoculated with P. viridiflava; 6, turnip leaf inoculated with Xanthomonas campestris pv. campestris; 7, turnip leaf inoculated with $P$. syringae pv. maculicola F18. were recovered from field 1 in the spring of 2000. In field 3, crop stubble was left undisturbed after harvest in the fall, and regrowth from the stubble occurred during the winter months. $X$. campestris pv. campestris and $P$. syringae pv. maculicola were isolated from the regrowth and surface debris of this field in December 1999 and March 2000 (Table 2).

Seed assays. In the assay of artificially inoculated seed, both $X$. campestris pv. armoraciae and $P$. syringae pv. maculicola were recovered when only one inoculated seed was added to $20 \mathrm{~g}$ of pathogen-free seeds. When two seeds, one inoculated with $X$. campestris pv. armoraciae and a second with $P$. syringae pv. maculicola, were added to $20 \mathrm{~g}$ of healthy seeds, both pathogens were recovered.

$X$. campestris pv. campestris was recovered from 6 of the 51 commercial seed lots surveyed. Infested seed lots included turnip (two seed lots), Chinese cabbage (two seed lots), spinach mustard (one seed lot), and

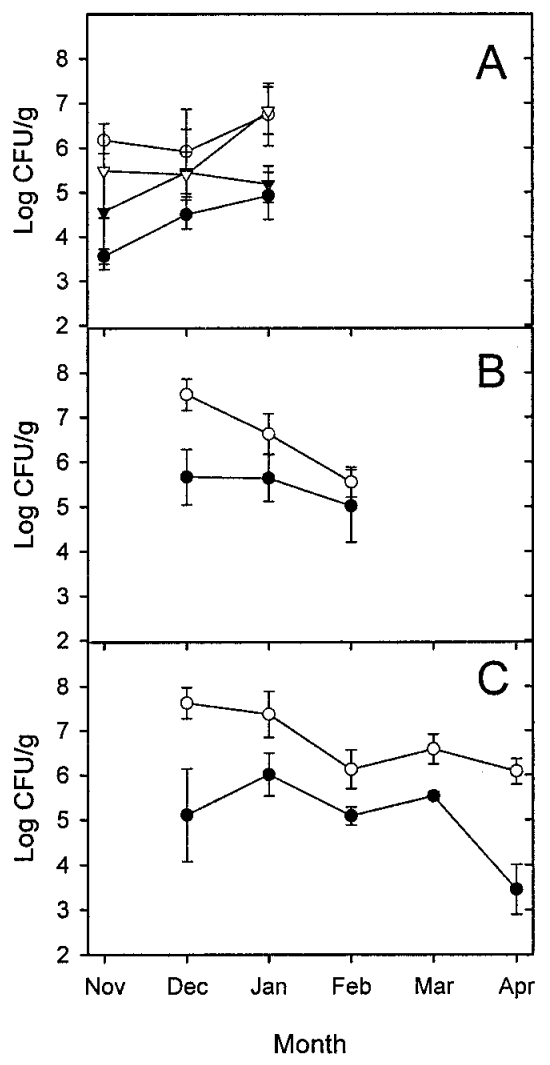

Fig. 2. Survival of rifampicin-resistant bacteria on plant debris during 1998 and 1999. PSM: Pseudomonas syringae pv. maculicola; XCA: Xanthomonas campestris pv. armoraciae. A, Pathogen recovery from early-planted turnip and collard plants buried $10 \mathrm{~cm}$ deep under soil. X. campestris pv. armoraciae on turnip (๑) and collards $(\boldsymbol{\nabla})$; P. syringae pv. maculicola on turnip $(\bigcirc)$ and collards $(\nabla)$. Recovery of $X$. campestris pv. armoraciae $(\bullet)$ and $P$. syringae pv. maculicola $(\mathrm{O})$ from late-planted turnip plants, B, buried $10 \mathrm{~cm}$ deep under soil, and $\mathbf{C}$, left on soil surface. Vertical bars represent one standard error of the mean. 
mustard (one seed lot). The cabbage cotyledon assay confirmed that the pathogen was $X$. campestris pv. campestris, and isolates varied in virulence (1) ranging from nonpathogenic for isolates from one seed lot of each mustard and Chinese cabbage to highly virulent for all other isolates. With the exception of mustard, the contamination level of seed lots was relatively low. The population of $X$. campestris in contaminated seed lots ranged from 1.5 to $370 \mathrm{CFU} / \mathrm{g}$ seed.

Fluorescent pseudomonads were recovered from 21 of the 51 seed lots. However, both conventional PCR and Bio-PCR indicated that the pseudomonads were not COR-producing strains of $P$. syringae pv. maculicola. The estimated population of fluorescent pseudomonads in the infested seed lots ranged from $4.64 \times 10^{4}$ to $1.31 \times$ $10^{6} \mathrm{CFU} / \mathrm{g}$ seed. Seed lots with the most recent harvest dates had the highest populations of fluorescent pseudomonads. $X$. campestris pv. armoraciae was not isolated from any of the seed lots.

\section{DISCUSSION}

$P$. syringae pv. maculicola produces $\mathrm{COR}$, a chlorosis-inducing phytotoxin that is also produced by $P$. syringae pathovars atropurpurea, glycinea, morsprunorum, and tomato (3). PCR primers and nucleotide probes have been used to identify phytotoxin-producing pathovars of $P$. syringae (3), including pathovars that synthesize COR $(3,7,8)$. In the present study, a simple method for preparing leaf extracts without isolating bacteria was developed that utilized small leaf sections (ca. $1 \mathrm{~cm}^{2}$ ) to de-

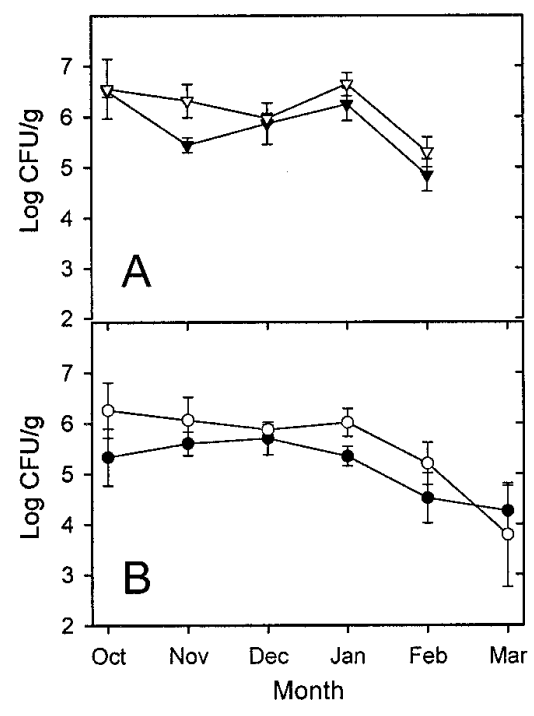

Fig. 3. Survival of rifampicin-resistant bacteria on plant debris left on the soil surface during 1999 and 2000. A, Recovery of Xanthomonas campestris pv. armoraciae $(\boldsymbol{\nabla})$ and Pseudomonas syringae pv. maculicola $(\nabla)$ from collards, and $\mathbf{B}, X$. campestris pv. armoraciae $(\bullet)$ and $P$. syringae pv. maculicola $(\mathrm{O})$ from turnip. Vertical bars represent one standard error of the mean. tect COR-producing $P$. syringae by PCR. This method can be used for the rapid detection of COR-producing pathovars of $P$. syringae since the results can be available within $24 \mathrm{~h}$. However, since other CORproducing pathovars may exist as epiphytes on diseased crucifers and survive the surface sterilization, pathogenicity tests are still necessary to unequivocally establish the presence of $P$. syringae pv. maculicola.

$X$. campestris pv. armoraciae and $P$. syringae pv. maculicola were less likely to survive in buried plant debris and more likely to persist in debris left on the soil surface. These results are consistent with previous studies; for example, survival of $P$. syringae pvs. phaseolicola and pisi was longer when plant debris remained on the soil surface $(11,29)$. X. campestris pv. glycines survived in plant debris located on the soil surface or buried at a depth of 10 $\mathrm{cm}$; however, fewer bacteria were recovered from buried samples (10). In our study, survival of bacteria in plant debris was associated with the longevity of the debris, which apparently relates to its treatment after harvest and environmental conditions. Mean monthly temperatures were above normal from November to February each year, which apparently favored rapid decomposition of buried plant debris in soil. The pathogens did not survive in buried debris in either trial until March or April when these crops are planted for spring production. In the 19992000 trial, plants were buried earlier and temperatures were warmer than in the 1998-1999 trial. In the 1998-1999 study, buried debris remained intact for 2 months; however, buried debris decomposed in less than 1 month during the 1999-2000 study. Other studies have demonstrated that higher temperatures stimulate the rapid decomposition of plant debris; consequently, bacteria are less insulated and populations decline more quickly $(13,16,17)$. However, bacterial survival in surface debris was less affected by environmental conditions as both pathogens persisted until spring planting time in each of the two trials reported here.

In Oklahoma, leafy crucifers are grown during spring and fall cropping seasons. Planting begins in March and September, with harvest following in May and November for the spring and fall production seasons, respectively. In general, growers moldboard plow fields at most every other year in the spring. Following harvest, fields are disk-harrowed once or twice as weather and soil conditions permit. Field preparation before planting involves one or two passes with a disk harrow. Although sampling was not performed in the summer, it is unlikely that infected plant debris would persist in the soil over the summer because high soil temperatures and irrigation during this period in Oklahoma would promote rapid residue decay. However, because the crop is harvested in bulk with nonselective cutters, crop residue and stubble remain on the soil after harvest. In field 3 where the stubble was not managed after harvest, regrowth of the stubble occurred during the winter of 1999-2000, when weather conditions favored the regrowth of plants and survival of the pathogens. Jardine et al. (12) reported that in fall-plowed treatments, tomato debris apparently decomposed before planting. For springplowed treatments, a large amount of intact tomato debris was present below or on the soil surface at planting time (12). This may explain why bacterial leaf spot diseases of leafy crucifers in Oklahoma have been observed to be more severe in the spring production season than in the fall (34). In Oklahoma, volunteer kale and turnip plants may be colonized by $X$. campestris pv. campestris, and plant debris on the soil surface and regrowth from stubble has a high potential to serve as inoculum for the next crop. However, infected crop residue incorporated into the soil may not be an important inoculum source.

Several cruciferous weeds have been reported to be hosts of $X$. campestris, including shepherd's purse, mouse-ear cress (Arabidopsis thaliana), and wild radish (Raphanus raphanistrum) (24,30). In Oklahoma, shepherd's purse occurred frequently in and around fields of leafy crucifers. Our results indicated that shepherd's purse is an alternative host for X. campestris pv. campestris in Oklahoma and may play an important role in the secondary disease cycle of black rot and leaf spot of crucifers caused by $X$. campestris pv. campestris, especially as a source for dispersal of the pathogen in the field. However, $X$. campestris pv. armoraciae and $P$. syringae pv. maculicola were not recovered from any of the weeds collected, suggesting that weed species may not be important in the epidemiology of these two pathogens.

The importance of seedborne inoculum of $X$. campestris pv. campestris has been well documented $(18,26)$. A very low level of seed infestation by $X$. campestris pv. campestris can result in a high incidence of black rot in the field (20). Our results showed that 6 out of 51 seed lots were contaminated with $X$. campestris pv. campestris, indicating that contaminated seed is a significant inoculum source in the epidemiology of black rot. Although $X$. campestris pv. armoraciae and $P$. syringae pv. maculicola are known to be seedborne $(18,27)$, we failed to recover these pathogens from seed. Since the detection procedure described in this study did not utilize large quantities of seed, it remains possible that $X$. campestris pv. armoraciae and $P$. syringae pv. maculicola may be seedtransmitted at a low level, and contaminated seed may play a role in the epidemiology of bacterial and Xanthomonas leaf spots. 
On the basis of our results, it is reasonable to suggest that crop residue management, elimination of volunteer plants and weeds, and the use of pathogen-free seed are important strategies in controlling leaf spot diseases of leafy crucifers in Oklahoma. A crop rotation program should also be followed to allow adequate time for the decomposition of infested debris. Thorough incorporation of crop residue would also be beneficial to hasten the decomposition of infested debris during the winter months. However, more research may be needed identify additional sources of inoculum for Xanthomonas and bacterial leaf spots. In the field surveys, these diseases were present on the crops in fields 1 and 4; yet the pathogens were not detected on any of the potential inoculum sources that were sampled. Levels of these pathogens may have been low and escaped detection at the time of sampling. Assessment of additional sources of inoculum may be necessary to identify other cultural practices for control of bacterial leaf spots.

\section{ACKNOWLEDGMENTS}

We thank Larry Littlefield and Nathan Walker for reviewing the manuscript. Approved for publication by the Director, Oklahoma Agricultural Experiment Station. This research was funded in part by the Oklahoma Agricultural Experiment Station project H2159 and National Science Foundation grants MCB-9807774 and IBN-0130693.

\section{LITERATURE CITED}

1. Alvarez, A. M., Benedict, A. A., Mizumoto, C. Y., Hunter, J. E., and Gabriel, D. W. 1994. Serological, pathological, and genetic diversity among strains of Xanthomonas campestris infecting crucifers. Phytopathology 84:1449-1457.

2. Alvarez, A. M., and Cho, J. J. 1978. Black rot of cabbage in Hawaii: Inoculum sources and disease incidence. Phytopathology 68:14561459.

3. Bender, C. L., Alarcón-Chaidez, F., and Gross, D. C. 1999. Pseudomonas syringae phytotoxins: Mode of action, regulation and biosynthesis by peptide and polyketide synthetases. Microbiol. Mol. Biol. Rev. 63:266292.

4. Bereswill, S., Bugert, P., Voelksch, B., Ullrich, M., Bender, C. L., and Geider, K. 1994. Identification and relatedness of coronatineproducing Pseudomonas syringae pathovars by PCR analysis and sequence determination of the amplification products. Appl. Environ. Microbiol. 60:2924-2930.

5. Black, L. L., and Machmud, M. 1983. Xanthomonas leaf spot of crucifers. Page 126 in: Int. Congr. Plant Pathol., 4th, Melbourne, Australia.
6. Campbell, R. N., Greathead, A. S., and Sim, S. T. 1987. Pepper spot of crucifers in California. Pages 668-671 in: Proc. Int. Conf. Plant Pathog. Bacteria, 6th. C. L. Civerolo, A. Collmer, R. E. Davis, and A. G. Gillaspie, eds. Martinus Nijhoff, Dordrecht, Netherlands.

7. Cuppels, D. A., and Elmhirst, J. 1999. Disease development and changes in the natural Pseudomonas syringae pv. tomato populations on field tomato plants. Plant Dis. 83:759-764.

8. Cuppels, D. A., Moore, R. A., and Morris, V. L. 1990. Construction and use of a nonradioactive DNA hybridization probe for detection of Pseudomonas syringae pv. tomato on tomato plants. Appl. Environ. Microbiol. 56:1743-1749.

9. Fukui, R. A., Arias, R., and Alvarez, R. 1994. Efficacy of four semiselective media for the recovery of Xanthomonas campestris pv. campestris from tropical soils. J. Appl. Bacteriol. 77:534-540.

10. Groth, D. E., and Braun, E. J. 1989. Survival, seed transmission, and epiphytic development of Xanthomonas campestris pv. glycines in the north-central United States. Plant Dis. 73:328-330.

11. Hollaway, G. J., and Bretag, T. W. 1997. Survival of Pseudomonas syringae pv. pisi in soil and on pea trash and their importance as a source of inoculum for a following field pea crop. Aust. J. Exp. Agric. 37:369-375.

12. Jardine, D. J., Stephens, C. T., and Fulbright, D. W. 1988. Potential sources of initial inoculum for bacterial speck in early planted tomato crops in Michigan: Debris and volunteers from previous crops. Plant Dis. 72:246249.

13. Jones, J. B., Pohronezny, K. L., and Jones, J. P. 1986. Survival of Xanthomonas campestris pv. vesicatoria in Florida on tomato crop residue, weeds, seeds, and volunteer tomato plants. Phytopathology 76:430-434.

14. Keane, P. J., Kerr, A., and New, P. B. 1970. Crown gall of stone fruit. II. Identification and nomenclature of Agrobacterium isolates. Aust. J. Biol. Sci. 23:585-595.

15. King, E. O., Ward, M. K., and Raney, D. E. 1954. Two simple media for the identification of pyocyanin and fluorescein. J. Lab. Clin. Med. 44:301-307.

16. Kocks, C. G., Ruissen, M. A., Zadocks, J. C., and Duijkers, M. G. 1998. Survival and extinction of Xanthomonas campestris pv. campestris in soil. Eur. J. Plant Pathol. 104:911-923.

17. McCarter, S. M., Jones, J. B. G., Gitaitis, R. D., and Smitley, D. R. 1983. Survival of Pseudomonas syringae pv. tomato in association with tomato seed, soil, host tissue, and epiphytic weed hosts in Georgia. Phytopathology 73:1393-1398.

18. Mguni, C. M., Mortensen, C. N., Keswani, C. L., and Hockenhull, J. 1999. Detection of the black rot pathogen (Xanthomonas campestris pv. campestris) and other xanthomonads in Zimbabwean and imported Brassica seed. Seed Sci. Technol. 27:447-454.

19. Miller, J. H. 1972. Experiments in Molecular
Genetics. Cold Spring Harbor Laboratory, Cold Spring Harbor, NY.

20. Randhawa, P. S., and Schaad, N. W. 1984. Selective isolation of Xanthomonas campestris pv. campestris. Phytopathology 74:268272.

21. Sambrook, J., Fritsch, E. F., and Maniatis, T. 1989. Molecular Cloning: A Laboratory Manual. 2nd ed. Cold Spring Harbor Laboratory, Cold Spring Harbor, NY.

22. Schaad, N. W. 1989. Detection of Xanthomonas campestris pv. campestris in crucifers. Pages 68-75 in: Detection of Bacteria in Seed and Other Planting Materials. A. W. Saettler, N. W. Schaad, and D. A. Roth, eds. American Phytopathological Society, St. Paul, MN.

23. Schaad, N. W., Cheong, S. S., Tamaki, S. Hatziloukas, E., and Panopoulos, N. J. 1995. A combined biological and enzymatic amplification (BIO-PCR) technique to detect Pseudomonas syringae pv. phaseolicola in bean seed extracts. Phytopathology 85:243-248.

24. Schaad, N. W., and Dianese, J. C. 1981. Cruciferous weeds as sources of inoculum of Xanthomonas campestris in black rot of crucifers. Phytopathology 71:1215-1220.

25. Schaad, N. W., and White, W. C. 1974. Survival of Xanthomonas campestris in soil. Phytopathology 64:1518-1520.

26. Schultz, T., and Gabrielson, R. L. 1986. Xanthomonas campestris pv. campestris in western Washington crucifer seed fields: Occurrence and survival. Phytopathology 76:13061309.

27. Sherf, A. F., and MacNab, A. A. 1986. Vegetable Diseases and Their Control. 2nd ed. John Wiley \& Sons, New York.

28. Wiebe, W. L., and Campbell, R. N. 1993. Characterization of Pseudomonas syringae pv. maculicola and comparison with $P$. s. tomato. Plant Dis. 77:414-419.

29. Wimalajeewa, D. L. S., and Nancarrow, R. J. 1980. Survival in soil of bacteria causing common and halo blights of French bean in Victoria. Aust. J. Exp. Agric. Animal Husb. 20:102-104.

30. Young, J. M. 1969. An alternative weed host for Xanthomonas campestris. Plant Dis. Rep. 53:820-821.

31. Zhao, Y., Damicone, J. P., Jones, W., Mitchell, R., and Bender, C. L. 2000. Detection of coronatine-producing strains of Pseudomonas syringae by PCR and ELISA. (Abstr.) Phytopathology 90:S88.

32. Zhao, Y. F., Damicone, J. P., and Bender, C. L. 2001. Sources of inoculum for bacterial leaf spot diseases of leafy crucifers in Oklahoma. (Abstr.) Phytopathology 91:S204.

33. Zhao, Y. F., Damicone, J. P., Demezas, D. H and Bender, C. L. 2000. Bacterial leaf spot diseases of leafy crucifers in Oklahoma caused by pathovars of Xanthomonas campestris. Plant Dis. 84:1008-1014.

34. Zhao, Y. F., Damicone, J. P., Demezas, D. H Rangaswamy, V., and Bender, C. L. 2000. Bacterial leaf spot of leafy crucifers in Oklahoma caused by Pseudomonas syringae pv. maculicola. Plant Dis. 84:1015-1020. 